\title{
RESEARCH IN SPORT \\ DHYSICA \\ Analysis of moderate aerobic exercise on the gut microbiota from mice induced to obesity with high fat diet
}

\author{
Autor(es): $\quad$ Ribeiro, Filipe M.; Castro, Aline P.; Ribeiro, Camila F. A.; Almeida, \\ Jeeser A.; Franco, Octavio L.; Petriz, Bernardo A.
}

Publicado por: Imprensa da Universidade de Coimbra

URL

persistente:

URI:http://hdl.handle.net/10316.2/44107

DOI:

DOI:https://doi.org/10.14195/2182-7087_ex2018_44

Accessed : $\quad$ 26-Apr-2023 14:55:13

A navegação consulta e descarregamento dos títulos inseridos nas Bibliotecas Digitais UC Digitalis, UC Pombalina e UC Impactum, pressupõem a aceitação plena e sem reservas dos Termos e Condições de Uso destas Bibliotecas Digitais, disponíveis em https://digitalis.uc.pt/pt-pt/termos.

Conforme exposto nos referidos Termos e Condições de Uso, o descarregamento de títulos de acesso restrito requer uma licença válida de autorização devendo o utilizador aceder ao(s) documento(s) a partir de um endereço de IP da instituição detentora da supramencionada licença.

Ao utilizador é apenas permitido o descarregamento para uso pessoal, pelo que o emprego do(s) título(s) descarregado(s) para outro fim, designadamente comercial, carece de autorização do respetivo autor ou editor da obra.

Na medida em que todas as obras da UC Digitalis se encontram protegidas pelo Código do Direito de Autor e Direitos Conexos e demais legislação aplicável, toda a cópia, parcial ou total, deste documento, nos casos em que é legalmente admitida, deverá conter ou fazer-se acompanhar por este aviso. 


\section{ANNALS OF RESEARCH IN SPORT AND PHYSICAL ACTIVITY}




\section{ANALYSIS OF MODERATE AEROBIC EXERCISE ON THE GUT MICROBIOTA FROM MICE INDUCED TO OBESITY WITH HIGH FAT DIET.}

Filipe M. Ribeiro1; Aline P. Castro²; Camila F. A. Ribeiro²; Jeeser A. Almeida³; Octavio L. Franco ${ }^{1}$; Bernardo A. Petriz ${ }^{4}$

Obesity is a multifactor disease associated with a high rate of mortality and morbidity worldwide. The gut microbiota is shown to be a key factor in the pathogenesis of obesity influencing the host metabolism. Diet and exercise were shown to modulate the gut microbiota ${ }^{(1-3)}$, however, this relation is still poorly understood. The present study was conducted to better understand the effect of aerobic exercise on the gut microbiota in animal model submitted to an obesity-inducing diet. Forty isogenic male C57BI/6J mice were divided into two groups; low-fat diet (10\%-LF, $n=20)$ and high-fat diet (60\%-HFD, n=20). After 16 weeks, all animals were submitted to four weeks of acclimatization and exercise adaptation to the treadmill apparatus. Furthermore, mice were divided into four groups; low-fat training (LFE $n=10)$, low-fat control (LFC, $n=10)$, high-fat training (HFE, $n=10)$ and, high-fat control (HFC, $n=10)$. All animals were submitted to a maximal velocity incremental test ( Vmax) for assessing the training intensity, set as 50\% of $V \max$, during $30 \mathrm{~min}^{\mathrm{d}} \mathrm{d}^{-1}, 5$ days/ week, for 8 weeks. For transcriptomic analysis, fecal content was collected prior to pre-dietary control, prior to the training program and after 8 weeks of training. Next Generation Sequencing Illumina MiSeq System of the 16S RNAr was used to analyze the effect of high-fat diet and training on the gut microbiota. The HF diet group presented a significant weight gain compared to the LF group, $(\sim 8,71 \mathrm{~g}, \mathrm{P}<0.0001)$. Training resulted in weight loss of the HFT group $(39,1 \mathrm{~g}, \mathrm{P}<0.05)$, compared to the HFC group $(44,3 \mathrm{~g}, \mathrm{P}<0.05)$. Moreover, Vmax in LFT group was improved after 4 weeks of training $\left(26.1 \mathrm{~m} \cdot \mathrm{min}^{-1}, \mathrm{P}<0.05\right)$, also reaching a longer distance $(375.4 \mathrm{~m}, \mathrm{P}<0.01)$ compared to the LFC group $(240 \mathrm{~m}, \mathrm{P}<0.0001)$. All DNA samples were successfully amplified. NGS is still in analysis, however, physiologic

\footnotetext{
${ }^{1}$ Center of Proteomic and Biochemical Analysis, Post-Graduation in Genomic and Biotechnology Sciences, Catholic University of Brasilia, Brasília, DF, Brazil.

2 Post-Graduation Program of Biotechnology, Catholic University Dom Bosco, Campo Grande, MS, Brazil.

${ }^{3}$ Federal University of Mato Grosso do Sul, Campo Grande, MS, Brazil.

${ }^{4}$ Department of Molecular and Exercise responses to Exercise, University center - UDF, Brasília-DF, Brazil.

Email: bernardopetriz@gmail.com; bernardo.assis@udf.edu.br
} 
data indicated that the proposed exercise program didn't lead to improvement in aerobic capacity in the HFE group. Despite the weight reduction due to training, the continuous HF diet may have negatively influenced animal's performance.

\section{ACKNOWLEDGEMENTS}

University Center UDF, Catholic University of Brasília, CNPq and FAP-DF

\section{REFERENCES}

1. Bermon, s., Petriz, b., Kajeniene, a., Prestes, j., Castell, I. \& Franco, o. L. (2015), "The microbiota: an exercise immunology perspective", Exerc Immunol Rev, Vol. 21, pp.70-9.

2. Kang, S. S., Jeraldo, P. R., Kurti, A., Miller, M. E., Cook, M. D., Whitlock, K., Goldenfeld, N., Woods, J. A., White, B. A., Chia, N. \& Fryer, J. D. (2014), "Diet and exercise orthogonally alter the gut microbiome and reveal independent associations with anxiety and cognition", Mol Neurodegener, Vol. 9, 36.

3. Petriz, P. A., Castro, A. P., Almeida, J. A., Gomes, C. P., Fernandes, G. R., Kruger, R. H., Pereira, R. w. \& Franco, O. L. (2014), "Exercise induction of gut microbiota modifications in obese, non-obese and hypertensive rats". BMC Genomics, Vol. 15, 511. 